\title{
$\mathrm{Mg}$ イオンを固溶した $\mathrm{PbTiO}_{3}$ 単結晶の育成及び評価
}

\author{
小舟正文・坂本千秋・藤井 知・杉江他曽宏 \\ (姫路工業大学応用化学科, 671-22 姫路市書写 2167)
}

\section{Growth and Characterization of $\mathrm{Mg}^{2+}$-Doped $\mathrm{PbTiO}_{3}$ Single Crystals}

\author{
Masafumi KOBUNE, Chiaki SAKAMOTO, Satoshi FUJII and Yosohiro SUGIE \\ (Department of Applied Chemistry, Himeji Institute of Technology, 2167, Shosha, Himeji-shi 671-22)
}

$\mathrm{PbTiO}_{3}$ single crystals with various quantities of added $\mathrm{Mg}^{2+}$ ions were grown by the flux cooling method using a platinum crucible. As-growm and poled $\mathrm{PbTiO}_{3}$ single crystals were used for measurement of pyroelectric properties.

(1) The added $\mathrm{Mg}^{2+}$ ions showed no significant effects on the crystal size and yield, but affected the crystal completeness.

(2) The $\mathrm{PbTiO}_{3}$ single crystals were reddish brown and highly transparent when the quantity of added $\mathrm{MgO}$ was in the range of 4000 to $6000 \mathrm{ppm}$. Using a microscope to observe the domain structure, it was confirmed that the crystals are composed of multidomains consisting of $180^{\circ}$ and $90^{\circ}$ domains.

(3) The axial ratio and the theoretical density of the crystal decreased with increasing $\mathrm{MgO}$ content. Based on the data of undoped crystals, the maximum decreases in the axial ratio and the theoretical density of $\mathrm{Mg}^{2+}$-doped crystals were approximately $1.88 \%$ and $3.31 \%$, respectively.

(4) From the measurement of pyroelectric constants, the pyroelectric coefficient $P$ and the figure of merit $F$. M. exhibited the highest values when the quantity of added $\mathrm{MgO}$ was $6000 \mathrm{ppm}$, reaching $2.7 \times 10^{-8} \mathrm{C} / \mathrm{cm}^{2} \cdot \mathrm{K}$ and $0.6 \times 10^{-10} \mathrm{C} \cdot \mathrm{cm} / \mathrm{J}$, respectively.

[Received March 14, 1988 ; Accepted May 26, 1988]

Key-words : $\mathrm{PbTiO}_{3}$ single crystal, $\mathrm{Mg}^{2+}$ ion, Crystal completeness, Multidomain, Axial ratio, Pyroelectric coefficient, Figure of merit

\section{1. 緒言}

$\mathrm{PbTiO}_{3}$ は近年, 非接触センサ, パイロビジコン及び 人体検知器など広く焦電形赤外線検出器に用いられてい る. その代表例として, $\mathrm{La}_{2 / 3} \mathrm{TiO}_{3}$ 及び $\mathrm{MnO}_{2}$ を添加す る方法 ${ }^{1)}$ と $\mathrm{Ca}$ 濃度を $24 \sim 28 \mathrm{~mol} \%$ の範囲とし, $\mathrm{Pb}^{2+}$ を $\mathrm{Ca}^{2+}$ で, $\mathrm{Ti}^{4+}$ を $\left(\mathrm{Co}_{1 / 2} \mathrm{~W}_{1 / 2}\right)$ で一部置換する方法 ${ }^{2}$ を 用いて作製した $\mathrm{PbTiO}_{3}$ 系セラミックスがあげられる.

ところが，上記の材料は以下の焦電材料に要求される 条件を十分に満足させるには至っていない.

（i）キュリー温度 $T_{\mathrm{c}}$ が高い.

(ii) 比誘電率 $\varepsilon_{\mathrm{r}}$ が小さい. $\left(\varepsilon_{\mathrm{r}}=100 \sim 150\right)$.

(iii) 材料評価指数 F.M. 及び F.M. $D^{*}$ が大きい.

（iv）極薄加工が容易である.

（v）組成の変動及び性能の経時劣化が少ない.

そこで，著者らは上記の諸条件に鑑み，材料特性を向 上させるため, $\mathrm{PbTiO}_{3}$ 単結晶の育成研究を行ってきた. 先の報告 ${ }^{3}$ では, $\mathrm{MgO}$ 単結晶製るつぼを用いた育成方 法及び焦電的諸定数について述べた. また, Mgイオン の固溶, 結晶完全性及び焦電特性に関する一連の研究か ら, その実用性についても考察した。一方, 直流抵抗率 の結果から, $\mathrm{Pb}$ 欠陥による負の電荷を補償するための $\mathrm{Mg}$ イオンの固溶量については, 広範囲での検討を要す
るものと判断された.

したがって, 本研究では, 更に結晶の高抵抗化をはか るとともに $\mathrm{Mg}$ イオンの添加量と焦電特性の関係を明 らかにするため, 種々 $\mathrm{Mg}$ イオンの添加量を変えて $\mathrm{PbTiO}_{3}$ 単結晶の育成を試みた。 なお, 実験は前報3) 同様のフラックス徐冷法で, 白金製るつぼを用いて行っ

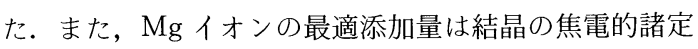
数, 特に材料評価指数に基づいて決定した.

\section{2. 実験方法}

\section{1 出発原料, フラックス, 添加剂及び使用したる} つぼ

出発原料として $\mathrm{PbTiO}_{3}$ 微粉末（山中セミコンダク 夕一製)を用いた.これは純度 $99.9 \%$ で不純物質として, $\mathrm{Fe}_{2} \mathrm{O}_{3}=0.008 \%, \mathrm{Na}_{2} \mathrm{O}=0.011 \%$ を含み, 一次粒子径 は走査型電子顕微鏡 (SEM) 観察から, 約 0.5 1.0 $\mu \mathrm{m}$ の範囲にあった．更に X 線回折により $\mathrm{PbTiO}_{3}$ 相で あることを確認した.

フラックスとして PbO (マシコット) 粉末（林純薬 製特級）を用いた.

添加剤として $\mathrm{MgCO}_{3}$ 粉末（関東化学製，特級）を用

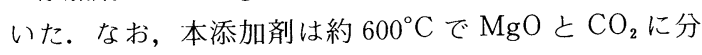




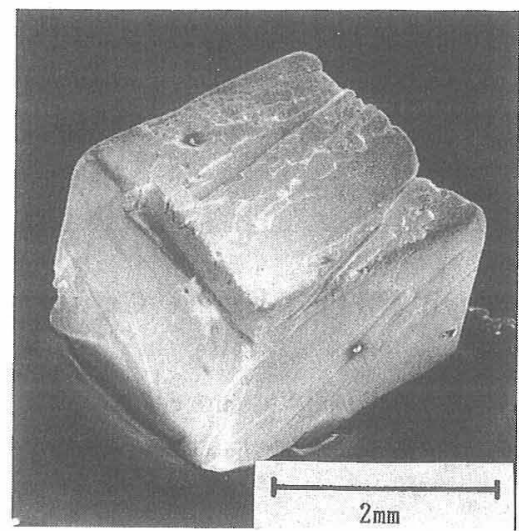

(a) No. $1-2: \mathrm{MgO}=100 \mathrm{ppm}$

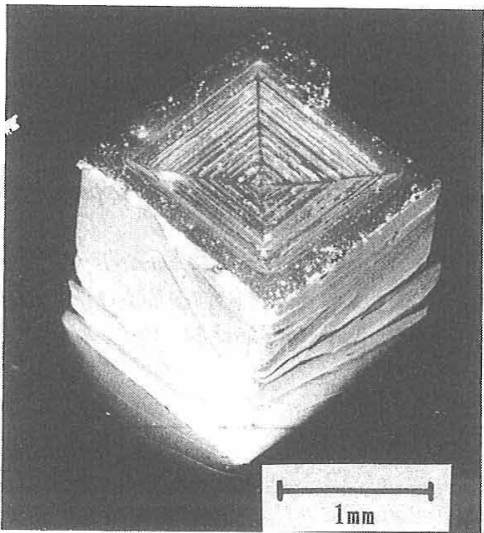

(c) No. 1-4: $\mathrm{MgO}=1000 \mathrm{ppm}$

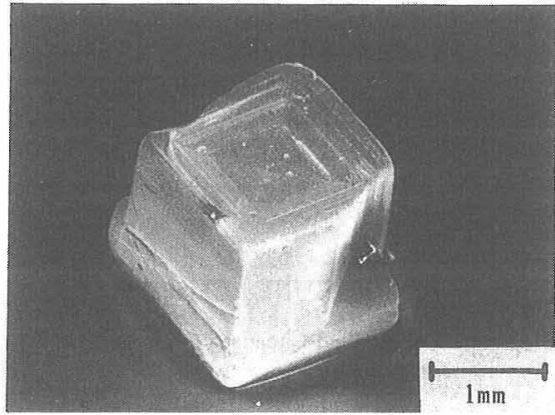

(b) No. 1-3: $\mathrm{MgO}=500 \mathrm{ppm}$

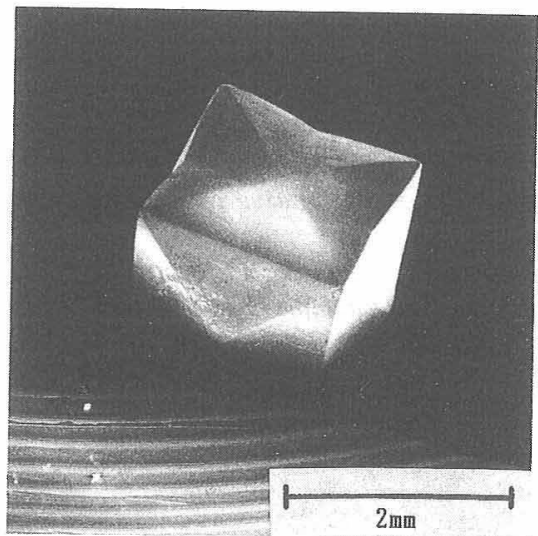

(d) No. 1-7: $\mathrm{MgO}=4000 \mathrm{ppm}$

Starting material $/$ Flux $=0.339$, Heating rate $=200^{\circ} \mathrm{C} / \mathrm{h}$, Soaking temperature $=1100^{\circ} \mathrm{C}$, Soaking time $=10 \mathrm{~h}$, Cooling rate $=$ $20^{\circ} \mathrm{C} / \mathrm{h}$.

Fig. 1. $\mathrm{SEM}$ photographs of $\mathrm{Mg}^{2+}$-doped $\mathrm{PbTiO}_{3}$ single crystal.

解することから，この使用に関し，以下 $\mathrm{MgO}$ の添加之 記す。

白金製るつぼは容積 $60 \mathrm{ml}$ を使用した。また，実験は 鉛蒸気が外部へ流出するのを防ぐため，白金製るつぼを 更に無吸水の $\mathrm{Al}_{2} \mathrm{O}_{3}$ 製るつぼ $(99.5 \%$ 以上，寸法：外 径 $78 \mathrm{~mm} \times$ 高さ $125 \mathrm{~mm}$ ) に入れて, 前報 ${ }^{3)}$ の図 1 と同 様の二重構造で行った。

\section{$2.2 \mathrm{PbTiO}_{3}$ 単結晶の育成方法}

出発原料/フラックス (重量比) $=0.339, \mathrm{MgO} /$ (出 発原料 $+\mathrm{MgO})=0.01 \sim 0.6 \mathrm{wt} \%$ となるように化学天科 で秤量し，白金製るつばに入れて十分にかくはん混合す る.次に原料を充填したるつぼを $\mathrm{Al}_{2} \mathrm{O}_{3}$ 製るつぼに入れ た後,二ケイ化モリブデンを発熱体とする横型電気炉(丸 祥電器製, Supermax) に装填し, 次の温度スケジュー ルに従って実験を行った。すすなわ，昇温速度 $200^{\circ} \mathrm{C} / \mathrm{h}$,
保持温度 $1100^{\circ} \mathrm{C}$ で $10 \mathrm{~h}$ 保持後, 徐冷速度を $20^{\circ} \mathrm{C} / \mathrm{h}$ と した.

育成結晶を取得するため, $2 \mathrm{~N} \mathrm{HNO}_{3}$ 中にるつぼを浸 漬し,かくはんすることで完全にフラックスを除去した。 得られた結晶は吸引沪過, 洗浄後, 恒温乾燥器で一昼夜 乾燥させた後，同定，顕微鏡観察及び諸定数の測定に供 した。

\section{3 育成結晶の成分分析及び観察}

育成結晶の成分分析及び観察には，それぞれ ICP 発 光分光分析装置（島津製作所製， ICPV-1000 W 型）及 び走査型電子顕微鏡（JEOL 製，JSM-T 300)，微分干 渉型顕微鏡（ニコン製，XPF-NR-B）を用いた。

\section{4 軸比及び理論密度の測定}

得られた結晶の室温における格子定数の測定に X 線 回折装置 (理学電機製, Geigerflex CN 2013) を用いて 
粉末法により行った. なお, 格子定数は高純度ケイ素粉 末 (半井化学製, $99.99 \%$ ) を内部標準にして, $\mathrm{PbTiO}_{3}$ の 002,200 回折から, 軸比は先の格子定数の比 $(c / a)$ から求めた。 また, 理論密度は $\mathrm{MgO}$ の固溶量及び格子 定数を用いて計算した.

\section{5 焦電的諸定数の測定}

育成結晶の $c$ 軸方向に垂直な両面を鏡面研磨し, そ の両面にスパッタリング装置を用いて Pt 電極を蒸着し た. 分極はシリコン油中で, $200^{\circ} \mathrm{C}, 50 \mathrm{kV} / \mathrm{cm}$ の直流 電界を 10 分間印加して行い，これを測定試料とした. その後, 比誘電率 $\varepsilon_{\mathrm{r}}$, 誘電損失 $\tan \delta$, 直流抵抗率 $\rho$ 及 び焦電係数 $P$ の測定を行った. $\varepsilon_{\mathrm{r}}$ 及び $\tan \delta$ の測定に はLCR メーター（YHP 製，4274 A 及び $4275 \mathrm{~A}$ ) を用 い, $1 \mathrm{kHz}$ 及び $1 \mathrm{MHz}$ において印加電圧 $15 \mathrm{~V} / \mathrm{cm}$ で室 温及び室温から $600^{\circ} \mathrm{C}$ の温度範囲で行った。 $\rho$ 及び $P$ の測定には微小電流計 (YHP 製, 4140 B) を用いて行っ た.なお， $P$ は室温から $120^{\circ} \mathrm{C}$ におる温度の上昇と 下降時の焦電電流の測定から算出した. そのほかの諸定 数, すなわち, 材料評価指数 F.M. は次式から求めた.

$$
F . M .=P / C_{\mathrm{v}} \cdot \varepsilon_{\mathrm{r}}
$$

ここで, $C_{\mathrm{v}}$ は体積比熱を表し, $C_{\mathrm{v}}=3.2 \mathrm{~J} / \mathrm{cm}^{3} \cdot \mathrm{K}^{4)}$ を用 いた.

更にキュリ一定数 $C$ 及びキュリー・ワイス温度 $T_{0}$ は 次式を使ってプロットした直線部分の勾配及び外挿法に より求めた.

$$
C=\varepsilon\left(T-T_{0}\right)
$$

\section{3. 実験結果及び考察}

3.1 Mgイオンを固溶した $\mathrm{PbTiO}_{3}$ 単結晶の育成及 び観察

\subsubsection{Mgイオンの添加効果}

予備実験において $\mathrm{MgO}$ の添加量を $7000 \mathrm{ppm}$ 以上と した場合, いずれも結晶方位の不確な塊状晶がるつぼ壁 に生成した.これらの結晶はるつぼ壁に強固に密着して いたため, 前記の実験方法による熱硝酸処理を施したに もかかわらず, 結晶を取得することはできなかった。し たがって, 以上の理由から本研究では $\mathrm{MgO}$ の添加範囲 からこれを除いて実験を行った.

前記の実験方法に従い, $\mathrm{MgO}$ の添加量を $0 \sim 6000$ ppm の範囲で変化させた実験結果を表 1 に示す．表か ら明らかなように, 結晶寸法は $\mathrm{MgO}$ の添加量が増加す るに従って減少する傾向にあった. また, 同様に無添加 のNo.1-1で最高収率を得た。しかしながら, 結晶完全 性の観点から No.1-7〜1-9 の結晶が特に良好であった. 以上の結果から, Mg イオンの添加効果は結晶寸法及び 収率に対し認められなかったが, 結晶完全性において顕 著に認められた。

\section{1 .2 育成結晶の成分分析及び観察}

前記の ICP 発光分光分析装置を用いて, 得られた結 晶の $\mathrm{MgO}$ 固溶量を測定したところ, $\mathrm{MgO}$ 固溶量は添 加量に一致した.これより本実験で添加した $\mathrm{MgO}$ はす ベて固溶していることがわかった.

次に No.1-2，1-3，1-4 及び 1-7 の育成結晶の SEM 写真を図 1 に示す. 図から, $\mathrm{MgO}$ 添加量が増加するに 従って結晶の緻密化が進み, 完全性が高められているの が観察される. また, 本実験において得られた結晶の色 調はNo. 1-3 1-5 で黒色, No. 1-6 で濃褐色, No. 1-7 〜1-9 で赤褐色であった. 特に, No. 1-7〜1-9 は透明度 の高い結晶であった. 図 2 に微分干渉型顕微鏡を用いて 観察した No.1-9 の (001) 面の分域模様を示す.この

\begin{tabular}{|c|c|c|c|c|c|c|c|c|}
\hline \multirow{2}{*}{$\begin{array}{l}\text { RUN } \\
\text { No. }\end{array}$} & Quantity of added & \multirow{2}{*}{$\begin{array}{l}\text { Yield } \\
\text { (מ) }\end{array}$} & \multirow{2}{*}{$\begin{array}{c}\text { Maximum crystal size } \\
(\mathrm{mm})\end{array}$} & \multicolumn{5}{|c|}{ Sieve analysis $(\not)$} \\
\hline & $(\mathrm{ppm})$ & & & $3.36 \mathrm{~mm}$ over & $3.36-2.83$ & $2.83-2.00$ & $2.00-1.00$ & $1.00 \mathrm{~mm}$ pass \\
\hline $1-1$ & 0 & 58.8 & $5.5 \times 5.5 \times 1.3$ & 15.5 & 16.6 & 9.7 & 35.9 & 22.3 \\
\hline $1-2$ & 100 & 56.2 & $4.0 \times 4.0 \times 1.5$ & 6.9 & 0 & 12.9 & 25.6 & 54.6 \\
\hline $1-3$ & 500 & 58.7 & $2.2 \times 2.2 \times 1.1$ & 0 & 0 & 10.4 & 46.7 & 42.9 \\
\hline $1-4$ & 1000 & 55.8 & $1.8 \times 1.8 \times 1.1$ & 0 & 0 & 0 & 44.3 & 55.7 \\
\hline $1-5$ & 2000 & 52.4 & $1.8 \times 1.8 \times 1.1$ & 0 & 0 & 0 & 24.0 & 76.0 \\
\hline $1-6$ & 3000 & 53.6 & $1.7 \times 1.7 \times 1.2$ & 0 & 0 & 0 & 33.7 & 66.3 \\
\hline $1-7$ & 4000 & 53.1 & $2.0 \times 2.0 \times 1.0$ & 0 & 0 & 0 & 18.0 & 82.0 \\
\hline $1-8$ & 5000 & 55.3 & $1.9 \times 1.9 \times 1.0$ & 0 & 0 & 0 & 16.5 & 83.5 \\
\hline $1-9$ & 6000 & 49.1 & $1.6 \times 1.6 \times 0.8$ & 0 & 0 & 0 & 3.0 & 97.0 \\
\hline
\end{tabular}

Table 1. Experimental data on single crystal growth of $\mathrm{Mg}^{2+}$-doped $\mathrm{PbTiO}_{3}$.

Starting material/Flux $=0.339$ (weight ratio), Heating rate $=200^{\circ} \mathrm{C} / \mathrm{h}$, Soaking temperature $=1100^{\circ} \mathrm{C}$, Soaking time $=10 \mathrm{~h}$, Cooling rate $=20^{\circ} \mathrm{C} / \mathrm{h}$ 


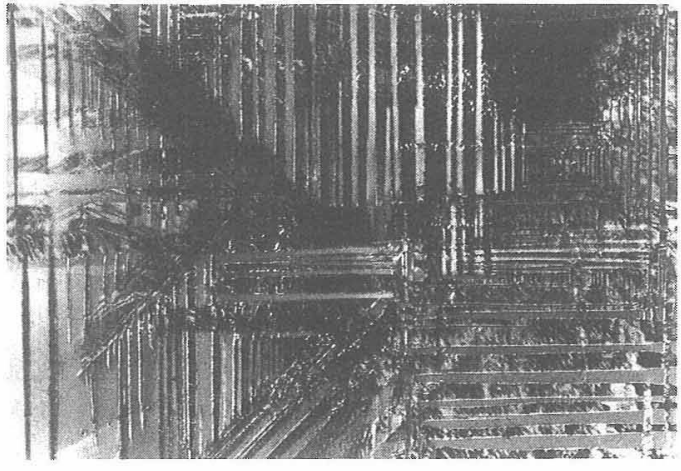

Fig. 2. Photomicrograph of multidomain of $\mathrm{Mg}^{2+}$. doped $\mathrm{PbTiO}_{3}$ single crystal.

ように本実験において得られた育成結晶はいずれも $180^{\circ}$ 分域及び $90^{\circ}$ 分域からなる複雑な分域構造を有して いた。

\section{2 格子定数, 軸比及び理論密度}

本結晶の格子定数を测定し, $\mathrm{Mg}$ イオンの固溶による 軸比及び理論密度の変化について調べた。表 2 及び図 3 は本実験で得られた結晶の格子定数, 軸比及び理論密度 を示している，図から明らかなように， $\mathrm{MgO}$ の添加量 の増加に従って, 軸比及び理論密度は徐々に減少した。 すなわち，表 2 におけるNo.1-1を基準にし，No.1-9 と比較した結果，軸比で約 $1.88 \%$, 理論密度で約 3. $31 \%$ の減少が見られた。このように, $\mathrm{MgO}$ 固溶量の 増加に従って結晶丕が減少することから，自発分極も同 様の減少傾向にあるものと推测される。

次に $\mathrm{Mg}$ イオンの固溶体形成について表 2 の格子定 数を用いて考察した。一般的に添加される原子が小さい
と，それは結晶の格子間に入って固溶体を形成する.し たがって，本結晶で添加される $\mathrm{Mg}$ 原子と $\mathrm{A}$ サイトの $\mathrm{Pb}$ 原子のイオン半径比が $\mathrm{Mg}^{2+} / \mathrm{Pb}^{2+} \doteqdot 0.53$ であるこ とから，Mgイオンは格子間に容易に侵入型固溶をする ことが予想される。一方, 育成過程において生じる $\mathrm{Pb}$ 欠宿に $\mathrm{Mg}$ イオンが部分的に置換型固溶をすることも 考えられる. 表の $\mathrm{MgO}=0$ - 3000 ppm の範囲では $a$ 軸 の増加及び $c$ 軸の減少が見られ，これらは $\mathrm{Mg}$ イオン の格子間への侵入型固溶と同時に一部の $\mathrm{Pb}$ サイトへの 置換型固溶によるものと思われる，亡ころが， $\mathrm{MgO}=$ 4000 6000 ppm の範囲では $a$ 軸の変化はほとんど見ら れず， $c$ 軸のみが減少する傾向にあった. これより, 上 記の範囲における $\mathrm{Mg}$ イオンの固溶体形成については, $\mathrm{Pb}$ サイトへの置換型固溶が大きく寄与していると考え られる。

\section{3 諸定数の測定}

前報3)では，分極処理に電場冷却法を適用したが，本 実験はシリコン油中で $200^{\circ} \mathrm{C}, 50 \mathrm{kV} / \mathrm{cm}$ の強電界を 10 分間印加する方法で行った。なお，3.1.1 項における No. 1-1〜1-6 の結晶は分極処理中に破断し，未分極時 の直流抵抗率を除く諸定数は測定不能であった。そこで， これまでに報告されている純粋な $\mathrm{PbTiO}_{3}$ 単結晶 ${ }^{51 ~ 8) 及 ~}$

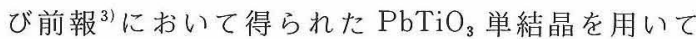
No. 1-7〜1-9 の本結晶と比較した.

\subsection{1 キュリー温度, 比誘電率及び誘電損失}

図 4 は前記試料の $\varepsilon_{\mathrm{r}}$ 及び $\tan \delta$ の温度依存性を示し たものである，図から本結晶は $T_{\mathrm{c}}$ 以上に加熱され，そ の後 $T_{\mathrm{c}}$ 以下に冷却されるとき，明確な温度履歴曲線を 示す。昇温時の $T_{\mathrm{c}}$ は $\mathrm{MgO}$ が $1000 \mathrm{ppm}$ 增加するごと に $8^{\circ} \sim 9^{\circ} \mathrm{C}$ の減少を示した。また $\varepsilon_{\mathrm{r}}$ は $T_{\mathrm{c}}$ に㧍いて極大

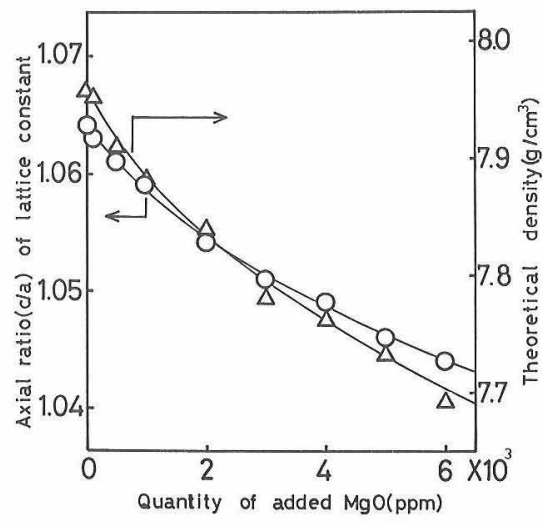

Fig. 3. Axial ratio of lattice constant, theoretical density vs. quantity of added $\mathrm{MgO}$ on $\mathrm{PbTiO}_{3}$ single crystals grown in this experiment.
Table 2. Quantity of added $\mathrm{MgO}$, lattice constant, axial ratio and theoretical density on $\mathrm{PbTiO}_{3}$ single crystals grown in this experiment.

\begin{tabular}{|c|c|c|c|c|c|}
\hline \multirow{2}{*}{$\begin{array}{l}\text { RUN } \\
\text { No. }\end{array}$} & Quantity of added & \multicolumn{2}{|c|}{ Lattice constant } & \multirow{2}{*}{$\begin{array}{l}\text { Axial ratio } \\
\text { c/a }\end{array}$} & \multirow{2}{*}{$\begin{array}{l}\text { Theoretical density } \\
(\mathrm{g} / \mathrm{cm})\end{array}$} \\
\hline & $\mathrm{MgO} \quad(\mathrm{ppm})$ & a $(\AA)$ & $\mathrm{c}(\AA)$ & & \\
\hline $1-1$ & 0 & 3.903 & 4.153 & 1.064 & 7.955 \\
\hline $1-2$ & 100 & 3.903 & 4.152 & 1.063 & 7.952 \\
\hline $1-3$ & 500 & 3.910 & 4.149 & 1.061 & 7.909 \\
\hline $1-4$ & 1000 & 3.912 & 4.146 & 1.059 & 7.880 \\
\hline $1-\hat{\jmath}$ & 2000 & 3.917 & 4.130 & 1.054 & 7.839 \\
\hline $1-6$ & 3000 & 3.918 & 4.119 & 1.051 & 7.780 \\
\hline $1-7$ & 4000 & 3.919 & 4.112 & 1.049 & 7.760 \\
\hline $1-8$ & 5000 & 3.919 & 4.100 & 1.046 & 7.732 \\
\hline $1-9$ & 6000 & 3.919 & 4.094 & 1.044 & 7.692 \\
\hline
\end{tabular}


Table 3. Comparison of pyroelectric properties on $\mathrm{PbTiO}_{3}$ single crystals.

\begin{tabular}{|c|c|c|c|c|c|c|c|}
\hline materials & $\begin{array}{l}\text { Quantity of added } \\
\mathrm{MgO}(\mathrm{ppn})\end{array}$ & $\begin{array}{l}\mathrm{T}_{\mathrm{c}} \\
\left({ }^{\circ} \mathrm{C}\right)\end{array}$ & $\varepsilon_{\mathrm{r}}$ & $\tan \delta$ & $\begin{array}{c}\rho \\
(\Omega \cdot \mathrm{cm})\end{array}$ & $\begin{array}{c}P \\
\left(\mathrm{C} / \mathrm{cth}^{2} \cdot \mathrm{K}\right)\end{array}$ & $\begin{array}{c}\text { F.M. } \\
(C \cdot \mathrm{cm} / \mathrm{J})\end{array}$ \\
\hline $\begin{array}{l}\mathrm{Mg}^{2+} \text {-doped } \mathrm{PbTiO}_{3} \text { single crystals } \\
\text { prepared in this experiment }\end{array}$ & 4000 & 497 & 138 & 0.08 & $6.0 \times 10^{9}$ & $1.0 \times 10^{-8}$ & $0.2 \times 10^{-10}$ \\
\hline & 5000 & 489 & 136 & 0.01 & $3.3 \times 10^{10}$ & $1.8 \times 10^{-8}$ & $0.4 \times 10^{-10}$ \\
\hline & 6000 & 480 & 132 & 0.008 & $6.8 \times 10^{10}$ & $2.7 \times 10^{-8}$ & $0.6 \times 10^{-10}$ \\
\hline $\begin{array}{l}\mathrm{PbTiO}_{3} \text { single crystal prepared } \\
\text { using a } \mathrm{MgO} \text { single crystal crucible }\end{array}$ & & 489 & 150 & 0.005 & $3.2 \times 10^{9}$ & $1.4 \times 10^{-8}$ & $0.3 \times 10^{-10}$ \\
\hline Pure $\mathrm{PbTiO}_{3}$ single crystals 5i 8 & & $495^{81}$ & 1007 & $\begin{array}{l}0.01 \\
\sim 0.17\end{array}$ & $\begin{array}{c}1.0 \times 10^{6} 51 \\
1.0 \times 10^{7} \\
2 \sim 5) \times 10^{10}\end{array}$ & $\longrightarrow$ & $\longrightarrow$ \\
\hline
\end{tabular}

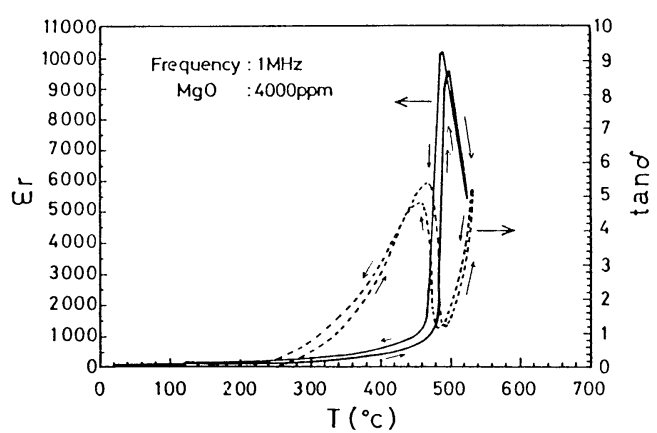

(a) No. 1-7: $\mathrm{MgO}=4000 \mathrm{ppm}$

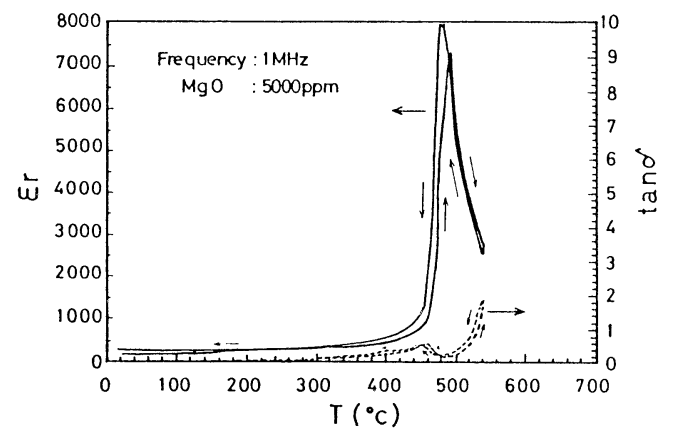

(b) No. $1-8: \mathrm{MgO}=5000 \mathrm{ppm}$

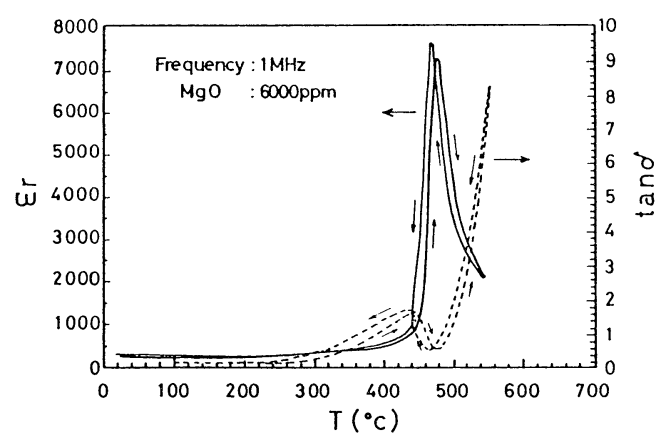

(c) No. 1-9: $\mathrm{MgO}=6000 \mathrm{ppm}$

Fig. 4. Temperature dependences of $\varepsilon_{\mathrm{r}}$ and $\tan \delta$ of $\mathrm{Mg}^{2+}$-doped $\mathrm{PbTiO}_{3}$ single crystals.
となるが，これについても $\mathrm{MgO}$ の添加量の増加に従っ てわずかに減少する傾向を示した. 更に, 表 3 の室温に おける $\varepsilon_{\mathbf{r}}$ も同様の傾向にあった.

一方，図中の $\tan \delta$ は $\varepsilon_{\mathbf{r}}$ と対照的な温度履歴曲線を 描いた．特に3.1.1 項におけるNo.1-7 の結晶はほかと 比較して, $300^{\circ} \mathrm{C}$ 付近から急激な増大を示している.こ のことは表 3 の室温における $\tan \delta$ からも容易に推測さ れるように，No.1-7 の結晶が内部に多くの結晶欠陥を 有することを示唆している. 以上の結果から，本結晶の $\tan \delta$ はg イオンの固溶量の増加にともなう結晶完全 性の向上により低減できたと考える.

\subsection{2 直流抵抗率及び電気伝導度}

図 5 は未分極及び分極後の本結晶の $\rho$ を示したもの である、図から，未分極の結晶に関し， $\mathrm{MgO}$ の添加量 の増加に従って $\rho$ が増大していることがわかる.この

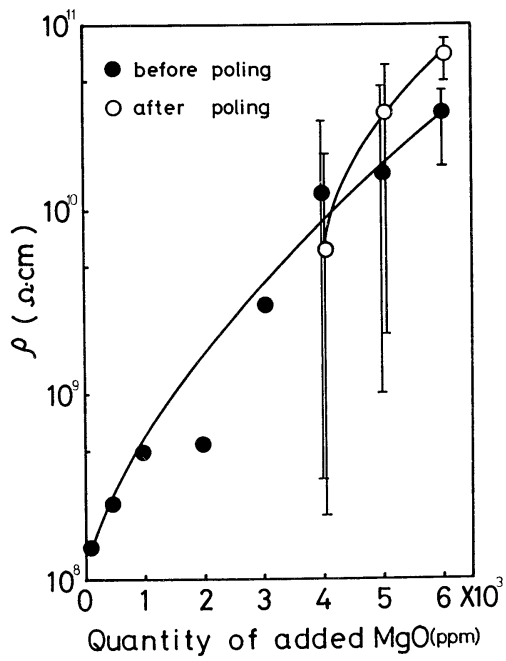

Fig. 5. Relation between quantity of added $\mathrm{MgO}$ and dc-resistivity. 
$\mathrm{T}\left({ }^{\circ} \mathrm{C}\right)$

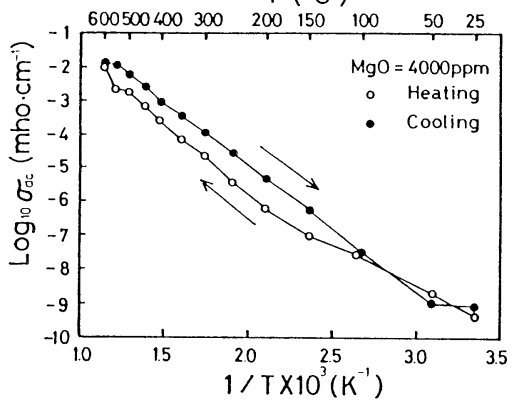

(a) No. 1-7: $\mathrm{MgO}=4000 \mathrm{ppm}$ $\mathrm{T}\left({ }^{\circ} \mathrm{C}\right)$

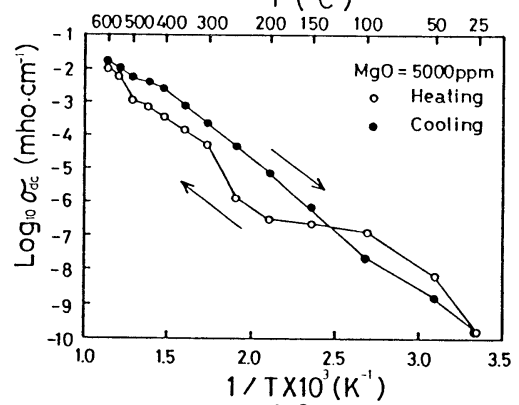

(b) No. $1-8: \mathrm{MgO}=5000 \mathrm{ppm}$

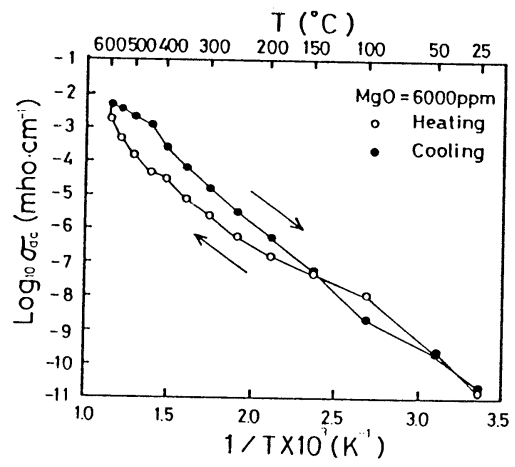

(c) No. 1-9: $\mathrm{MgO}=6000 \mathrm{ppm}$

Fig. 6. Conductivity of $\mathrm{Mg}^{2+}$-doped $\mathrm{PbTiO}_{3}$ single crystal as a function of temperature.

ことから, $\mathrm{Pb}$ 欠陥の負の電荷を $\mathrm{Mg}$ イオンが補償し高 抵抗化がなされたものと推察される. また, 分極により No.1-8 及び 1-9 の試料では, 平均值で約 2 倍の効果が 認められた。一方, No.1-7 の試料では, 平均值で約 $1 / 2$ に低下した. 以上の結果から, 分極は $\rho$ 及び結晶完 全性に大きく依存しているものと考える．次に先の分極 試料を $T_{\mathrm{c}}$ 以上に加熱し, その後室温まで冷却する間の 電気伝導度 $\sigma_{\mathrm{dc}}$ の温度特性を調べた.これを図 6 に示す. これまで $\sigma_{\mathrm{dc}}$ の挙動についてはRemeika と Glass の報 告 ${ }^{5)}$ がある. この挙動に関し, 比較した結果, 本試料の アレニウスプロットが直線的であったのに対し, Remeika とGlass の結晶は曲線的であった. また，本試料 の No.1-9 における $600^{\circ} \mathrm{C} て ゙ の ~ \sigma_{\mathrm{dc}}$ は Remeika と Glass
の結晶の約 $1 / 3$ に相当した。したがって，前記試料は表 3 の室温の $\rho$ からも明らかなようにこれまで報告され ている $\mathrm{PbTiO}_{3}$ 単結晶 ${ }^{5) ~ 8)}$ と比較して最も優れていた.

\subsection{3 焦電係数及び材料評価指数}

図 7 は本実験において作製した試料の焦電係数の温度 依存性を示したものである，実用上，特に室温付近にお ける焦電係数の温度変化は小さいことが望ましいことか ら本試料は焦電形赤外線素子の最適な材料と言えよう. 表 3 の $P$ 及び $F . M$. から, 前報 ${ }^{3)}$ で得られた結晶は本 実験の No.1-8にほぼ一致した. また，本実験において 最も高い $P$ 及び $F . M$. はNo.1-9 の試料で得られ，そ れぞれ, $2.7 \times 10^{-8} \mathrm{C} / \mathrm{cm}^{2} \cdot \mathrm{K}$ と $0.6 \times 10^{-10} \mathrm{C} \cdot \mathrm{cm} / \mathrm{J}$ であっ た. 以上の結果から, 本研究における $\mathrm{MgO}$ の最適添加 量は $6000 \mathrm{ppm}$ であるとの結論に達した. 今後, 更に焦 電係数の理論值 $\left.{ }^{9}\right)$ に近づけるため, $\mathrm{Mg}$ イオンと $\mathrm{A}$ サイ トに置換型固溶し得る陽イオンの組み合わせによる検討 を行いたい.

\subsection{4 キュリー定数及びキュリー・ワイス温度}

本実験で作製した試料のキュリ一定数及びキュリー・

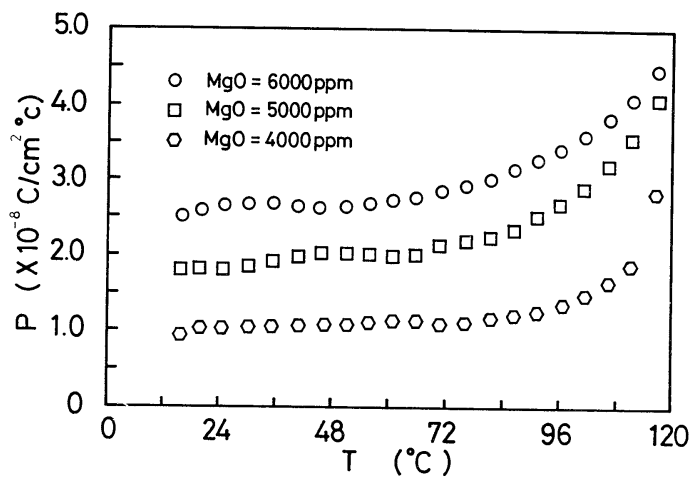

Fig. 7. Temperature dependence of pyroelectric coefficient for $\mathrm{Mg}^{2+}$-doped $\mathrm{PbTiO}_{3}$ single crystals.

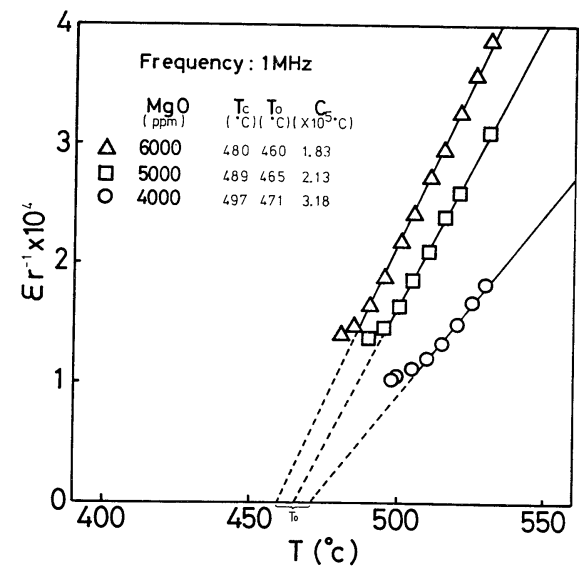

Fig. 8. Above the Curie temperature, the Curie constant and the Curie-Weiss temperature of $\mathrm{Mg}^{2+}$-doped $\mathrm{PbTiO}_{3}$ single crystals. 
ワイス温度は ( 2 ) 式を使って, プロットした直線部分 の勾配及び外挿法により求めた.その結果を図 8 に示す. これによると, $\mathrm{MgO}$ の添加量の増加に従って, キュリー 定数及びキュリー・ワイス温度は徐々に減少する傾向に あった. また, 図よりキュリー・ワイス温度がキュリー 温度より $20^{\circ} \sim 26^{\circ} \mathrm{C}$ 低いことから, 本結晶は相転移の際 に潜熱をもつ, いわゆる一次の相転移 ${ }^{51,10)}$ を示す強誘電 体単結晶と考えられる.

\section{4. 総 括}

白金製るつぼを用い, 種々 $\mathrm{Mg}$ イオンの添加量を変 えてフラックス徐冷法により $\mathrm{PbTiO}_{3}$ 単結晶の育成を 行った. また, その結晶評価についても検討した. 結果 は次のとおりである.

（1）本実験における Mgイオンの添加効果は結晶 寸法及び収率に対し認められなかったが, 結晶完全性に おいて顕著に認められた。

(2) 本実験で育成された $\mathrm{PbTiO}_{3}$ 単結晶は $\mathrm{MgO} の$ 添加量が 4000 6000 ppm の範囲において, 赤褐色で高 い透明度を有していた. また，顕微鏡による分域構造の 観察から育成結晶はいずれも $180^{\circ}$ 分域及び $90^{\circ}$ 分域か らなる多分域状態にあることが確認された.

（3）本実験において得られた結晶の軸比及び理論密 度は $\mathrm{MgO}$ の添加量の増加に従って徐々に減少する傾向 にあった. $\mathrm{Mg}$ イオンを固溶した結晶の軸比及び理論密
度は無添加の結晶を基準にし, 最大でそれぞれ, 約 $1.88 \%$ と約 $3.31 \%$ の減少を示した.

(4) 焦電的諸定数の測定結果から, 焦電係数 $P$ 及 び材料評価指数 F.M. は $\mathrm{MgO}$ の添加量が $6000 \mathrm{ppm}$ に おいて最高值を示した. その值はそれぞれ， $2.7 \times 10^{-8}$ $\mathrm{C} / \mathrm{cm}^{2} \cdot \mathrm{K}$ と $0.6 \times 10^{-10} \mathrm{C} \cdot \mathrm{cm} / \mathrm{J}$ であった.

謝辞 本研究の諸定数の測定については, 松下電器産業 (株) 中央研究所・材料グループの上田一朗博士並びに飯島賢 二博士, 夕テ木化学工業 (株) 第二研究開発の栗栖裕文氏の御 協力を得ました. 深く感謝の意を表します.

\section{文献}

1) 上田一朗, 小林 茂, 池上清治, National Tech. Rept., 18, 413-25 (1972).

2) N. Ichinose, Y. Hirao, M. Nakamoto and Y. Yamashita, J.J. Appl. Phys., 24, 463-65 (1985).

3）小舟正文, 坂本千秋, 窯協, 95, 1053-58 (1987).

4) H.P. Beerman, Infrared Physics, 15, 225-31 (1975).

5) J.P. Remeika and A. M. Glass, Mater. Bull., 5, 37-46 (1970).

6) B.C. Grabmaier, Feroelectrics., 13, 501-03 (1976).

7) V. G. Gavrilyachenko, R. I. Spinko, M. A. Martynenko and E. G. Fesenko, Soviet Physics-Solid State, 12, 1203-04 (1970).

8) V.G. Bhide, K. G. Deshmukh and M. S. Hegde, Physica, 28, 871-76 (1962).

9) K. Iijima, S. Kawashima and I. Ueda, Proc. 3rd Sensor Symp., 133-36 (1983).

10）犬石嘉雄, 中島達二, 川辺和夫, 家田正之, “誘電体現象 論”, 電気学会 (1973) pp. 157-58. 